\title{
Tidewater: A Metropolitan Toponym for Southeastern Virginia? ${ }^{1}$
}

\section{Justin C. Friberg and Donald J. Zeigler}

Norfolk. Portsmouth. Chesapeake. Suffolk. Virginia Beach. Hampton. Newport News. They range from some of the oldest settlements on the Atlantic coast to some of the nation's newest "suburban cities." They retain their separate political identities, yet they have grown together geographically and economically to form a metropolitan community of 1.3 million people at the mouth of the Chesapeake Bay, identified by the U. S. Census Bureau as the Norfolk-Virginia Beach-Newport News Metropolitan Statistical Area (Fig. 1). The historical dominance of Norfolk, and to a lesser degree, Portsmouth, Hampton, and Newport News, has given way to up-and-coming suburban entities such as Chesapeake and Virginia Beach, the latter of which is now the state's most populous city.

Today, the region lacks a single, dominant urban center and has therefore been challenged to find a metropolitan toponym that transcends the political barriers which divide it into seven major jurisdictions and several minor ones. To fill the need for a comprehensive regional appellation, several vernacular designations have emerged, the most popular and most controversial of which has been Tidewater. When the U.S. Postal Service consolidated its services and opened a new regional mail handling facility in 1983, a decision to institutionalize the Tidewater name was implemented. The Tidewater postmark had been selected in the mid-1970s following meetings between postal authorities and elected officials. Its inauguration, however, initiated a spirited and continuing public debate over what to call the greater metropolitan region. This debate immediately focused on Tidewater's imprecise configuration in the collective public consciousness and engendered a proposal to make a competing designation, Hampton Roads, the official, over-arching regional term for this sprawling metropolitan area. One national magazine, in fact, announced that "Tidewater Virginia has disappeared" and is now called Hampton Roads (Reinhart 39). Today, these terms remain in conflict and several alternative toponymic futures, some of which do not include Tidewater, may be projected. In this paper we will attempt to explain the reasons for the rise and fall of the 


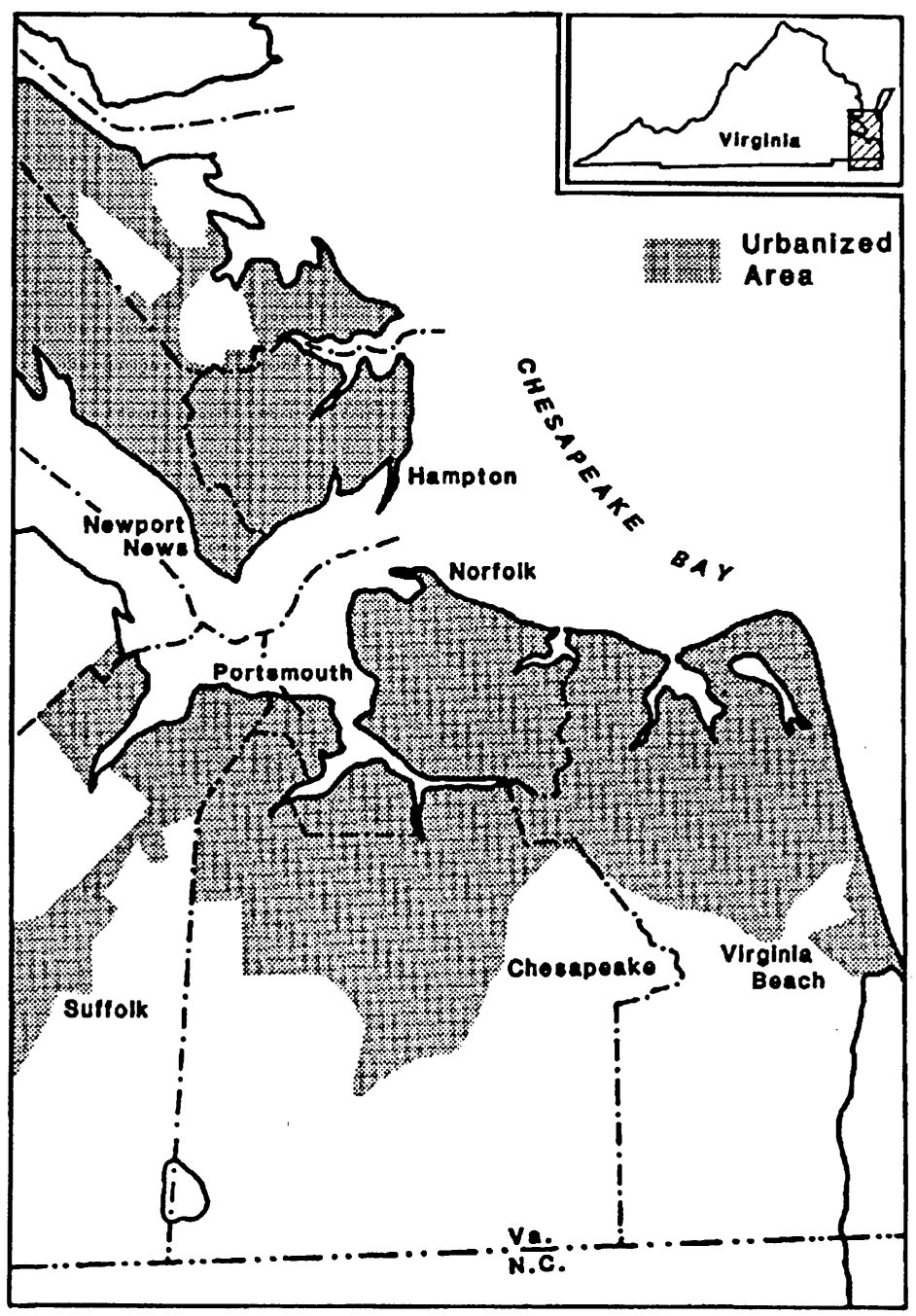

Fig. 1. The Seven Cities of Southeastern Virginia.

Tidewater postmark and the debate which ensued. First, we will explore the emergence and development of the sobriquet; second, we will identify the area to which the vernacular name applies; and third, we will explore the difficulties of adopting a vernacular designation for the purposes of public administration. 


\section{Vernacular Regions}

Tidewater is what may be referred to as a vernacular region, a distinctive area where the inhabitants collectively consider themselves closely interlinked by a shared history, mutual interests, and a common identity. Regions of this nature comprise part of a colloquial locational reference system which is popularly used to separate "here" from "there," and "us" from "them." They are "intellectual inventions" and, as Ruth Hale has put it, "a necessary form of shorthand for the identification of things, people, and places"(131). Vernacular regions reflect a "sense of place" but rarely coincide with established jurisdictional borders.

Interest in vernacular regions seems to have accompanied the development of behavioral and perceptual themes in the social sciences and particularly geography. Joseph W. Brownell's survey of postmasters in 1960 to delimit the elusive "Midwest" and Gary Dunbar's article on the popular regions of Virginia were among the first attempts to define regional geographies on the basis of public perceptions. Brownell's study has recently been updated by James $\mathbf{R}$. Shortridge who has attempted in two articles to define not only the territorial extent of the vernacular Midwest but also its conceptual image. Dunbar's study has been followed by a series of state studies which has included Arkansas, Florida, Kansas, Oklahoma, and Texas. ${ }^{2}$ Corollary research has focused on "vernacular boundaries," such as those separating "upstate" and "downstate" New York, "northern" and "southern" California, and the imaginary borders of "Southern Indiana" and "South Jersey.",

Vernacular regions are dynamic entities that appear and disappear and often change name and shape to accommodate technological developments, new environmental circumstances, and changing social values; yet, most of the literature has portrayed their configurations at a particular point in time. We have little information about the factors that might affect the emergence, development, and demise of these regions. Nor do we have much information about the structure and dynamics of vernacular regions at the metropolitan level, despite the fact that three-quarters of the American population lives in metropolitan areas. Because the origins of vernacular regions are spontaneous and mundane, because they rest in the minds and pepper the conversations of the common folk, and because the nuances of speech are often obscured in what does appear in cold print, the difficulties of tracing their evolution are almost insurmountable. 


\section{Origins And Development Of The Name Tidewater}

By scrutinizing a few early references to "Tidewater Virginia," we have pieced together a sequence of uses that provides some clues to its development as a vernacular region. The evolution of the Tidewater terminology can be traced through a series of historical stages which may be conveniently summarized as the incipient, the attributive, and the explicit stages. These stages may serve as a model which may help us to better understand the transition in meaning from a mere concept to a vernacular region, a process by which Tidewater came to distinguish a particular area from others according to selected and widely acknowledged characteristics.

The origins of vernacular regional names are not rooted in the proceedings of the past, but rather emerge from the everyday working language of a people. In the incipient stage, a simple concept, such as a topographic term with descriptive and practical applications becomes part of a common lexicon. The term "tide water," usually expressed as two words and sometimes hyphenated, is English in origin and refers to "water brought by the flood tide" ( $O E D$, s.v. "tide-water"). Although reference sources provide us little corroborating information, the earliest use of the term likely referred to a specific hydrographic concept which differentiated between high and low water levels. Undoubtedly, "tide water" was part of the stock of terms brought by the early English-speaking colonists and applied to similar environments in eastern Virginia where livelihoods were oriented toward the estuarine waterways. Janet H. Gritzner found that "generic" names were often rooted in the general vocabulary practiced in the area and that waterways were commonly named according to their navigational qualities (238). More than a simple place-name that merely labels and locates a feature, Tidewater can be considered a "generic" name which connotes its amphibious physical character.

The second, or attributive, stage is introduced by the addition of a partially formulated locational dimension associated with what had been previously expressed as a simple concept. Probably by the mid-eighteenth century the term "tide-water" assumed an attributive form such as "tide-water country" or "tidewater Virginia," which was used to describe the topographic character of those areas affected by the tides. Evidence of this transformation is disclosed in Thomas Jefferson's Notes on the State of Virginia. Based on his travels in 17711772 , Jefferson as a geographic observer divided the seventy-four counties of Virginia into four physiographic provinces: 
Of these 35 are on the tide waters, or in that parallel; 23 are in the Midlands, between the tide-waters and Blue Ridge of mountains; 8 between the Blue Ridge and Alleghaney; and 8 westward of the Alleghaney. (108) ${ }^{4}$

On the very next page, Jefferson clearly refers to the tidewaters as an object rather than as a concept upon mentioning "the towns at the head of the tidewaters." Later in some appended notes he summarizes a series of elevations "above the Tidewater" and subsequently makes references throughout to "Tidewater" as a capitalized single word. The contextual use in the latter case implies a distinct, identifiable area.

In the final or explicit stage in the historical development of a vernacular region, a pervasive popular image has emerged among the people. Popular usage acknowledges both a well-defined territorial extent and a distinctive set of qualitative associations. By the mid-1800s the word Tidewater appears to have been firmly established in the common parlance to refer to a vernacular region, coextensive with the low-lying coastal plain contiguous to the Chesapeake Bay and its riverine estuaries. Two maps by Jedediah Hotchkiss, "Map of Tide-water Virginia" (1873) and "Virginia's Natural Grand Divisions" (1884) both identify the tidewater as synonymous with the coastal plain of eastern Virginia (LeGear). One reference seems to capture both the regional and consensual image that had emerged by the late nineteenth century:

It would be hard to find elsewhere upon the North American coast any region where the land is so generally and easily penetrable by streams that can be navigated. The country known as "tidewater Virginia" is a kind of sylvan Venice. Into the depths of the shaggy woodland for many miles on either side of the great bay the salt tide ebbs and flows. (Fiske 224)

In Virginia today most physical geographers and geologists continue to accept the terms coastal plain and tidewater as synonymous. In his definitive midtwentieth century geography of Virginia, for instance, Jean Gottmann refers to the coastal plain as Tidewater (146). This definition makes it possible to trace Tidewater as far inland as Richmond, Fredericksburg, and Alexandria on the "fall line," the eastern escarpment of the piedmont plateau. Defined as a 
landform region, Tidewater has very precise boundaries and covers an extensive geographic area. In a more recent development the traditional application of the term Tidewater to the coastal plain has been legitimized in a document no less prestigious than the Code of Virginia, the official record of Commonwealth statutes. In order to qualify for federal support for the Virginia Wetlands Act (1973), the legislature established a legal Tidewater jurisdiction. In the code the area is synonymous with the vast coastal plain, encompassing thirty-one counties or roughly one-fourth the territorial extent of the Commonwealth.

\section{The Metropolitan Appropriation Of The Name Tidewater}

Unfortunately, the historical definition of Tidewater has come into conflict with popular usage. When a Virginian identifies his home as Tidewater, it is widely understood within the state to mean the metropolitan area at the mouth of the James River. People from other parts of the coastal plain may acknowledge their Tidewater location, but they are more likely to identify themselves as being from the Eastern Shore, The Peninsula, the Middle Peninsula, or the Northern Neck, all of which are regional terms that Dunbar identified as "popular regions" of Virginia in 1961 (Fig. 2). On Dunbar's map the southeastern corner of the state is not included in any region, but he did note that "the term Tidewater is heard most commonly in the Norfolk area, probably because it is the only section of the coastal plain that does not bear a distinctive popular name" (10). Even the region labelled "Southside" is shown to terminate before reaching the Norfolk vicinity.

Though frequently used, however, the official designation of the area served by the new mail handling facility as Tidewater brought cries of protest from many segments of the local community. The criticism revolved around four major points. First, Tidewater was perceived to lack well-defined boundaries. It was at once both too inclusive, covering the entire coastal plain, and too exclusive, being limited in many minds to the cities of Norfolk, Portsmouth, and part of Virginia Beach and Chesapeake. Many jurisdictions within the postal district maintained that they were not in Tidewater and did not want their mail postmarked as such. Others agreed that they were in Tidewater but felt that the region was too imprecisely defined to use as the official postmark.

Second, Tidewater was alleged to lack exclusivity. Any coastal region could legitimately use the term Tidewater for the area lapped by the flowing tide. 


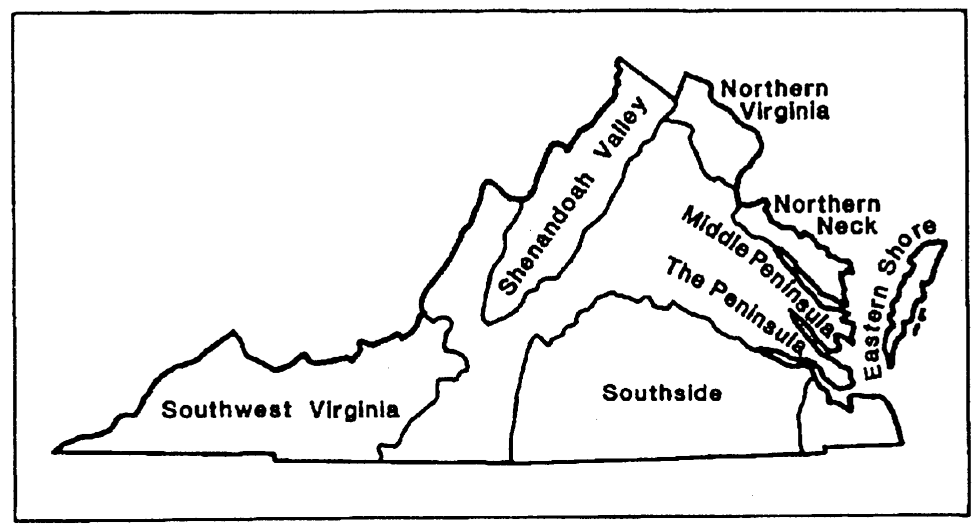

Fig. 2. Virginia's Popular Regions According to Gary Dunbar.

Third, the term could not be found in atlases and on maps because there was no specific place named Tidewater, thus depriving the area of national and international identity. Fourth, Tidewater was proclaimed by many as not an attractive enough term on which to promote commerce and tourism. One columnist wrote there is "no romance to it. It makes me think of bilge water" (Bonko). As an alternative to Tidewater, the term Hampton Roads was proposed, and the mayors of the seven cities unanimously voted in favor of its adoption by the U.S. Postal Service. Their decision was not without precedent: On the official state highways map, for instance, the metropolitan region has been identified as Hampton Roads since 1936. Moreover, proponents claimed that Hampton Roads was more precisely and locally defined than Tidewater and already had an international reputation as one of the largest ports in the United States. A brief two months after the Tidewater postmark made its appearance, it was officially replaced by Hampton Roads. In addition, the Hampton Roads Chamber of Commerce and a think-tank called Hampton Roads Futures (but formerly called Tidewater Futures) now seek the elimination of the Tidewater vernacular and the universal acceptance of Hampton Roads for the larger metropolitan area. Despite their reported dissatisfaction with the Tidewater appellation, however, the local population continues to use that term more frequently than Hampton Roads. 


\section{Where Is Tidewater?}

In order to evaluate criticisms of the Tidewater epithet and to determine its regional configuration, we carried out several cognitive and unobtrusive analyses. First, we surveyed a group of university students to determine where they perceived Tidewater to be. Second, we determined the locations of businesses and other organizations which carried Tidewater, Hampton Roads, and The Peninsula in their names, a method used in other studies by Wilbur Zelinsky, Charles Stansfield and Elizabeth Strasser, and Terry G. Jordan.

To determine cognitive images of Tidewater we surveyed students in several introductory geography classes who were given a map of Virginia and bordering states. The map was accompanied by these instructions: "This map includes parts of Virginia, North Carolina, and Maryland. We are interested in finding out where you consider TIDEWATER to be. Please draw a boundary line on your map showing the limits of what you think is the Tidewater area." Our survey sample size was 124 , from which we selected the sixty-four maps drawn by students who had lived in the local area ten years or more. Over each of these maps we imposed a grid of half-inch squares and tallied the number of times each square was included in the area perceived as Tidewater. The resulting map (Fig. 3) shows the core of Tidewater to be restricted to the NorfolkVirginia Beach-Portsmouth area, with a relatively rapid distance decay outward from this center. Note as well the impact of the Virginia-North Carolina state boundary on perceptions of Tidewater, the absence of the Eastern Shore from almost all respondents' maps, and the uniformity with which the area hugs the western coast of the bay to the north. Only a slim minority of students who participated in the survey extended the regional boundaries of Tidewater beyond the seven cities region.

Additionally, we examined 1982-83 telephone directories from all cities and counties in eastern Virginia and nearby North Carolina, and noted those businesses identified as Tidewater. Our results yielded several hundred entries ranging from "Tidewater Anesthesiologist" to "Tidewater Zoological Society." The locations of these establishments are portrayed in Fig. 4. Easily recognizable on the map is the heavy concentration of Tidewater businesses in southeastern Virginia, with Norfolk alone accounting for 118 telephone directory entries. Beyond the seven cities at the mouth of the James River, there were very few businesses using the Tidewater designation. Even in Newport News and Hampton the Tidewater terminology was not as popular among 


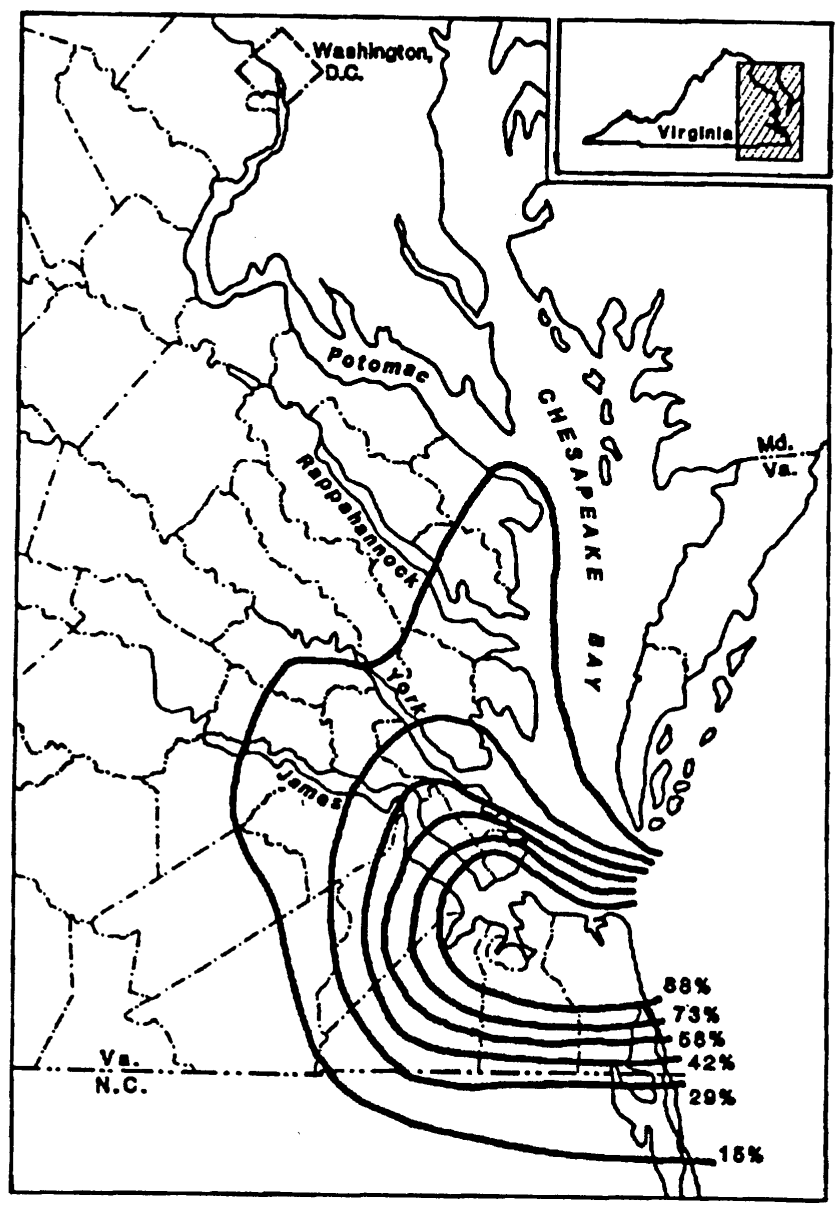

Fig. 3. Tidwater as Defined by Student Perceptions.

businessmen, probably because of competition from their own vernacular term, The Peninsula.

Many organizations played an active role in promoting the development of a unified metropolitan consciousness by using the Tidewater name. The name has been frequently adopted by businesses to appeal to a market area beyond local jurisdictional boundaries. Public and private services, such as Tidewater Regional Transit and Tidewater Automobile Association, adopted the name to 
describe their service areas. And the mass media have applied the name to promote a shared community identity. For example, a local CBS-TV affiliate adopted a "Hello Tidewater" theme in 1982-83 to galvanize a regional viewing audience, and the Sunday edition of the The Virginian Pilot includes a section called "Tidewater Living."

As a competing term, however, Hampton Roads has proven to be much less popular to date than either Tidewater or The Peninsula among local merchants, civic and professional associations, and service agencies in southeastern Virginia. In the 1984 telephone directory for Norfolk-PortsmouthChesapeake- Virginia Beach, there were 323 Tidewater entries and only forty for Hampton Roads. In the 1985 Hampton-Newport News telephone directory, Tidewater listings numbered eighty-two; Hampton Roads listings, fifty-six; and Peninsula listings, 162. Moreover, Hampton Roads has been used almost exclusively for marine and industrial enterprises, whereas Tidewater has been applied to automobile dealerships, home building and maintenance organizations, professional corporations, and even a children's museum. Judging from the types of establishments to which both names have been applied, Hampton Roads connotes an image of industrial, commercial, and maritime development, whereas Tidewater seems to capture the lifestyle of the region and is applied to a broad spectrum of businesses, especially those that enrich the amenity base of the area.

The results of both of our surveys reinforce the previously noted discrepancy between the region referred to as Tidewater by physical and historical geographers, and the vernacular region which is more limited in scope. How did the term Tidewater come to be restricted to metropolitan southeastern Virginia? With the exception of the urban region on the lower James, the other major metropolitan centers of Virginia are located where major rivers cut across the fall line. On the bay itself the seven cities region represents the most sizable concentration of people in the zone where the tidal flux is the most obvious. Because there were more people here to use the term, their influence may have gradually been responsible for a more localized territorial definition, a process which probably paralleled the inter-city coalescence that has accelerated since the end of World War II. In fact, according to a former editor of the Norfolk newspaper, a longitudinal inventory of "Tidewater" telephone directory listings netted only three entries in 1900, fifty-three in 1950, and 115 in 1977 (Jenkins).

To evaluate the criticism that Tidewater is a common name along the United States coast and therefore not distinctive, two additional analyses were 


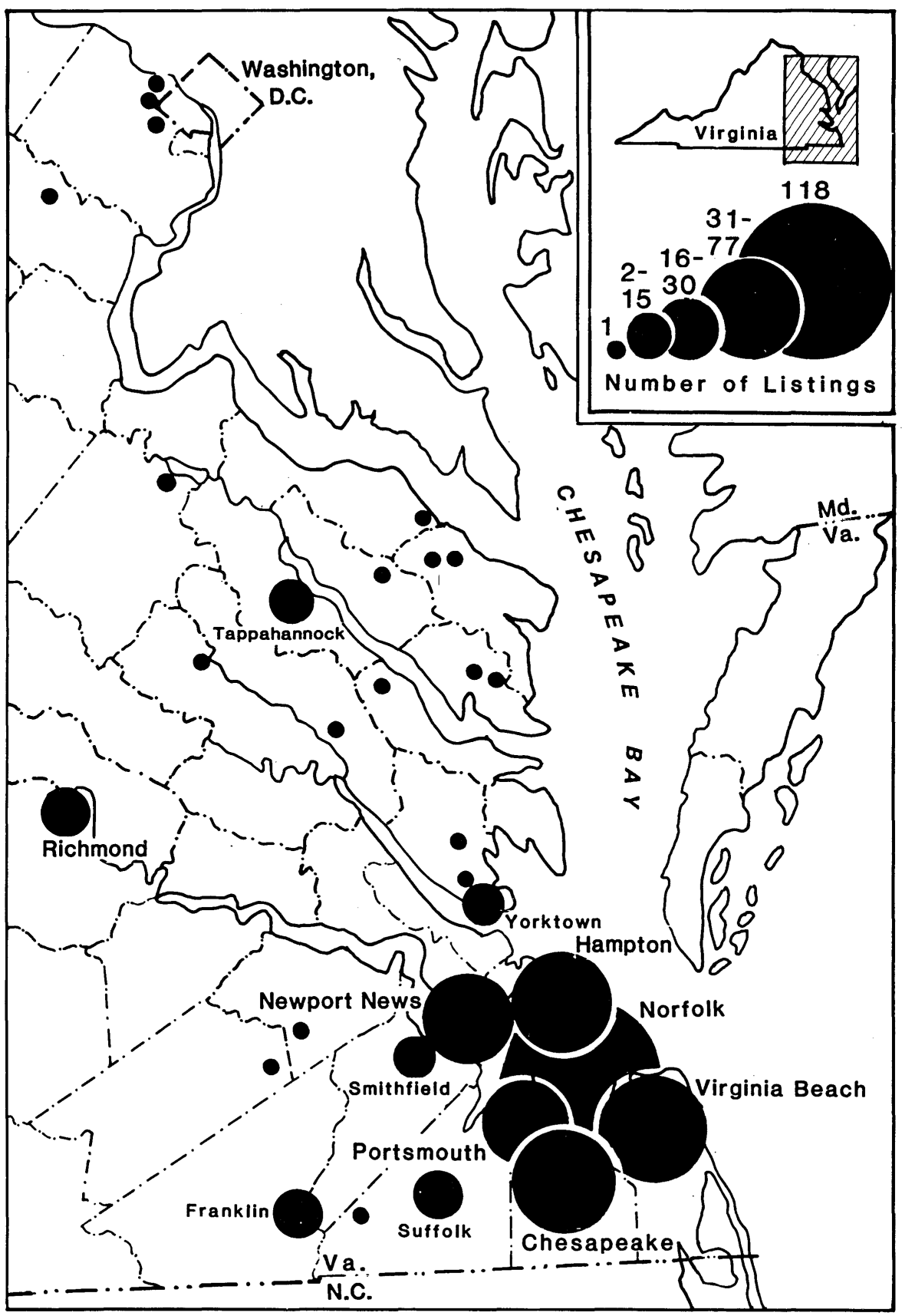

Fig. 4. Tidewater Listings in Telepone Directories of Eastern Virginia. 
performed. First, we tabulated the number of times Tidewater appeared as a corporate name in thirty metropolitan area telephone directories along the Atlantic and Gulf coasts. Only in the Baltimore and Annapolis, Maryland, directories were more than ten listings found. ${ }^{5}$ Second, we ran a search of the U.S. Geological Survey's Geographic Names Data Base of the Geographic Names Information System. The data base contains fifty-seven files representing all states and territories of the United States and includes at a minimum all names appearing on the U.S.G.S. topographic quadrangle map series. Only once in Oregon and once in Virginia does the name Tidewater appear as the name of a populated place in the GNIS file. In Virginia the place identified is a small hamlet on the Northern Neck, within the coastal plain but far from the metropolitan agglomeration to its south. The computer search was able to turn up only three additional instances of Tidewater appearing on the landscape in conjunction with other features in Texas and Florida. A check of the Rand McNally Commercial Atlas and other maps revealed only two other Tidewater placenames, one in West Virginia and another in southern Louisiana. As a formal toponym, therefore, Tidewater seems to be exceedingly rare. As a vernacular designation, with the important exception of Maryland, it also seems to be limited to the southeastern Virginia metropolitan area. It does not appear to be a common formal or vernacular name anywhere in the United States except in the region around the Chesapeake Bay.

\section{Whither Tidewater?}

By 1983, Tidewater had become a well-established vernacular term for the metropolitan area of southeastern Virginia. Little thought seems to have been given to the geographic extent of the vernacular region until the local population was confronted with a toponymic identity crisis precipitated by the appearance of the Tidewater postmark. The question of a name for the larger metropolitan area called for an immediate decision. What was once a collection of places near the mouth of the Chesapeake Bay had now become a single place but a place without an official name. The debate that ensued evidenced both a regional self-consciousness that transcends jurisdictional boundaries and the degree to which people do care about the toponyms which are selected to designate the places where they live. It also illustrates how a popular vernacular designation may be rejected as a formal toponym, perhaps because of the very 
property that makes it a good vernacular term-its flexible and amorphous definition.

The people and their elected officials prevailed upon the PostmasterGeneral and, for lack of a better alternative, Hampton Roads was chosen as a regional name. At least Southeastern Virginia has never been seriously considered as an official designation for the local area, probably because of the richness of indigenous names and the desire not to mimic the naming practices of the District of Columbia's Virginia suburbs which have long used the Northern Virginia postmark. In the jockeying for official status, Hampton Roads was chosen, Southeastern Virginia was never considered, and Tidewater was rejected. Several conflicts may have contributed to the fall of the Tidewater postmark: First, the conflict between federal and local decision-making power; second, the conflict between the broad territorial extent of the coastal plain and the narrowness of a term used most frequently in Norfolk and contiguous places; and third, a conflict between the historical rural imagery of Tidewater plantations and the modern urban imagery of Tidewater cities.

At the present time the drama of placenaming continues. The need for a single metropolitan term was perhaps best summarized by William $D$. Mayer in a keynote speech before Hampton Roads Futures, Inc.: "If we do not agree with one voice who we are and what we're called, it is going to be very difficult to communicate that to the rest of the Commonwealth, let alone the nation and the world" (Lackey). In less than two years after the Tidewater postmark first appeared, the parochial issue of how to cancel the mail had grown into a crusade of international importance. Dr. Mayer spoke in favor of Hampton Roads, a term chosen by the leadership community and a term which must now attempt the transition from official toponym to vernacular region, a transition which the vernacular Tidewater could not make in the opposite direction.

In the struggle over official and vernacular metropolitan toponyms, Tidewater may survive only as a nickname to be used informally among friends and neighbors. What appears to be emerging, however, is a hierarchy of vernacular designations. Hampton Roads may filter into the local vocabulary for the larger metropolitan region, but the physical barrier of the roadstead itself divides the area into two distinct parts, the north side of Hampton Roads which is widely known and referred to as "The Peninsula" and the south side of Hampton Roads which may become the even more geographically restricted Tidewater of the future. "The Peninsula" seems to be secure in the local parlance, but even as a regional term for a subdivision of the greater Hampton 
Roads area, Tidewater suffers from competition with other emerging vernacular references. Both South Hampton Roads and Southside Hampton Roads are becoming increasingly popular among the local population. Nevertheless, the Tidewater label continues to be used, however amorphously, in the everyday speech of the local area, and the naming dilemmas that afflict southeastern Virginia are undoubtedly repeated across the American landscape as other "twin-city," "tri-city," and "quad-city" areas try to select names that capture the regional self-consciousness of evolving metropolitan places.

\section{Old Dominion University, Norfolk, Virginia}

\section{Notes}

1. The authors are indebted to Timothy Fariel and Eugenio Rodriguez for their assistance in analyzing the student survey results and the telephone directory listings, the results of which were presented at the annual meeting of the Virginia Social Science Association in 1983. In addition, we would like to thank Mr. Mark Hodges, Jr., former Manager-Postmaster, Norfolk Sectional Center, U.S. Post Office, fo rsharing his account of the Tidewater postmark dispute.

2. See Good, "Vernacular Regions of Arkansas"; Lamme and Oldowski; Shortridge, "Vernacular Regions of Kansas"; Zdorkowski and Carney; and Jordan. Examples of studies that have addressed larger subnational vernacular regions include Reed and Raitz and Ulack.

3. See Phillips; Miller; Good, "A Perceptual Delimitation"; Gesler, and Stansfield and Strasser.

4. See also Brown.

5. Although no specific Tidewater placename is listed in Maryland, the term is used informally in the upper reaches of the Chesapeake Bay. See, for example, Singlewald and Slaughter. Another unconfirmed report identified a Tidewater area in the vicinity of Galveston, Texas.

\section{Works Cited}

Bonko, Larry. "Put Your Stamp on a Postmark."The Ledger Star (Norfolk, Va.), 4 Feb. 1983.

Brown, Ralph H. "Jefferson's Notes on Virginia." Geographical Review 33 (1933): 467-473.

Brownell, Joseph W. "The Cultural Midwest."Journal of Geography 59 (1960):43-61.

Dunbar, Gary S. "The Popular Regions of Virginia." University of Virginia Newsletter 38 (1961): 10-12.

Fiske, John L. Old Virginia and Her Neighbors. Boston: Houghton-Mifflin, 1897 
Gesler, Wilbert M. "North Jersey vs. South Jersey: A Population Geography Class Survey." Joumal of Geography 80 (1981): 124-129.

Good, James K. "A Perceptual Delimitation of Southern Indiana," Professional Paper No. 8, Department of Geography and Geology, Indiana State University, Terre Haute, Indiana, 1976.

. “The Vernacular Regions of Arkansas." Journal of Geography 80 (1981): 179-181.

Gottmann, Jean. Virginia at Mid-Century. New York: Holt, 1955.

Gritzner, Janet H. "Seventeenth Century Generic Place-Names: Culture and Process on the Eastern Shore." Names 20 (1972): 231-239.

Hale, Ruth F. "Vernacular Regions of America.," Joumal of Cultural Geography 5 (1984): 131. Jefferson, Thomas, Notes on the State of Virginia. Ed. William Peden. Chapel Hill: U of North Carolina P, 1955.

Jenkins, Kent, Jr., "Stamp of Disapproval: 'No' Vote by Council on 'Tidewater' Postmark." The Beacon (Virginia Beach, Va.), 17/18 Feb. 1983.

Jordan, Terry G. "Perceptual Regions of Texas," Geographical Review 68 (1978): 293-307.

Lackey, Patrick K. “Area Urged to Sharpen its Image." The Ledger-Star (Norfolk, Va.), 16 Dec. 1984.

Lamme, Ary J., III, and Raymond K. Oldowski. "Vernacular Areas in Florida." Southeastern Geographer 32 (1982): 99-109.

LeGear, Clara Egli. The Hotchkiss Map Collection. Washington: Sterling P, 1951.

Miller, Willis H. "Where is Southern California?" California Geographer 22 (1982): 67-93.

Phillips, Betty S. "Upstate and Downstate in New York," Names 31 (1983): 4150.

Raitz, Karl, and Richard Ulack, "Appalachian Vernacular Regions," Joumal of Cultural Geography 12 (1981): 106-119.

Reed, John S. "The Heart of Dixie: An Essay in Folk Geography." Social Forces 54 (1976): 925-939.

Reinhart, Kellee C. "The Art of Regionalism." Horizon 27 (June 1984): 39-41.

Shortridge, James R. "The Emergence of 'Middle West' as an American Regional Label." Annals of the Association of American Geographers 74 (1984): 209-220.

. "The Vernacular Middle West." Annals of the Association of American Geographers 75 (1985): 48-57.

. "Vernacular Regions of Kansas." American Studies 21 (1980): 73-94.

Singlewald, J. T., and T. H. Slaughter, Shore Erosion in Tidewater, Maryland, Maryland Department of Geology, Mines, and Water Research Bulletin No. 6, 1949. 
Stansfield, Charles, and Elizabeth Strasser, "Identifying a Vernacular Region." Association of American Geographers Annual Meeting, Los Angeles, April 1981.

Zelinsky, Wilbur. "North American Vernacular Regions." Annals of the Association of American Geographers 70 (1980): 1-16.

Zdorkowski, R. Todd, and George O. Carney, "This Land is My Land: Oklahoma's Changing Vernacular Regions." Joumal of Cultural Geography 5 (1985): 97-106.

\section{THE NORTH CENTRAL NAME SOCIETY}

Established in 1980 as the Illinois Name Society, NCNS expanded its scope and changed its name in 1985. Membership is open to anyone with an interest in names. Membership dues are $\$ 10$ per year. Tojoin, please write the Secretary, Laurence E. Seits, English Department, Waubonsee Community College, Sugar Grove, IL 60554.

NCNS accepts for publication manuscripts on any aspect of names. Write to the Secretary, Laurence Seits, or the President, Edward Callary, English Department, Northern Illinois University, DeKalb, IL 60115. Manuscripts should follow The MLA Style Manual (1985), with parenthetical documentation. 